\title{
直径の異なるコア供試体の強度 RELIABILITY OF COMPRESSIVE 試験結果の信頼性に関する検討 STRENGTH TEST RESULTS USING VARIOUS DIAMETER CORES
}

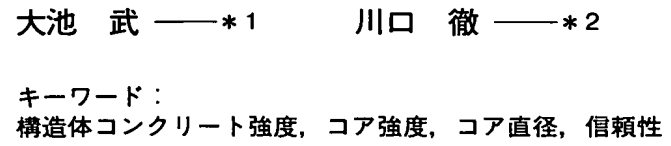

Keywords :

Concrete strength in structures, Strength of cores, Diameter of cores, Reliability
Takeshi OHIKE $-* 1$ Toru KAWAGUCHI $-* 2$

This paper describes an investigation into the reliability of compressive strength test results using various diameter cores.

The following conclusions were obtained,

1) Decreasing core diameters led to dispersion of compressive strengths, and compressive strengths became too low compared with standard compressive strengths.

2) When the core specimen diameter was under $50 \mathrm{~mm}$, care must be talen in evaluating the test results.
1.はじめに

地球環境の保護、資源の有効利用から建物の長寿命化が求められ ている。R C 構造物の長寿命化を図る上で計画的な維持管理が欠か せない。維持管理の基本データとして R C 構造物中のコンクリート 強度の調査がある。 R C 構造物中のコンクリート強度を調査する⿱丶万仒 法として、非破壊試験と破壊試験の 2 つがある。非破罗試験は破壊 試験に比べ試験結果の信頼性に限界がある。破罗試験としては構造 物から抜き取ったコア供試体を用いる方法が一般的である。赛用的 な観点からは、できるだけ直径の小さいコア供試体で信頼性の高い 結果が得られることが望ましい1，2)。

ここでは、標準の強度試験用供試体（ $\phi 100 \times 200 \mathrm{~mm} ）$ と同時に 成型した供試体（ $(150 \times 300 \mathrm{~mm} ）$ からコア供試体を抜き取り、両 者の強度試験を行い、直径の異なるコア供試体の強度試験結果の信 頼性について比較検討した。

\section{2. 試験概要}

\section{1 コンクリート試験}

\subsection{1 試験の要因と水準}

試験に用いたコンクリートは、一般 RC 構造物から超高層 RC 構 造物に用いられる設計基準強度をカバーできるように、調合上の水 セメント比を $25 \% 、 30 \% 、 40 \% 、 50 \% 、 60 \% の 5$ 水準とした。

コア供試体の直径は、水セメント比 $40 \%$ 以上のコンクリートを対 象とした試験は、 $\phi 20 、 \phi 30 、 \phi 50 、 \phi 75$ ならびに $\phi 100$ の 5 水 淮とした。直径 $\phi 20$ のコア供試体は一部で実施した。水セメント比 $25 \% 、 30 \%$ の超高強度コンクリートを対象とした試験では、 $\phi 50$ 、 $\phi 75$ ならびに 100 の 3 水淮とした。

圧縮強度試験は、材齡 4 週及び 13 週の 2 水準で実施した。養生方 法は、標準養生の 1 水準とした。

試験の要因と水準を整理して表 -1 に、コンクリートの調合を表 2にそれぞれ示した。

\subsection{2 コンクリートのフレッシュ性状}

コンクリートのフレッシュ性状は、水セメント比 $40 \%$ 以上のコン クリートでは、スランプ $15 \pm 2.5 \mathrm{~cm}$ 、空気量 $4.5 \pm 1.5 \%$ とした。水 セメント比 $25 \%$ 、30\%の超高強度コンクリートでは、スランプフ

\section{表一 1 実験要因と水準}

\begin{tabular}{|c|c|c|}
\hline 要因 & 水準 & 備考 \\
\hline コア直径 & 5 & 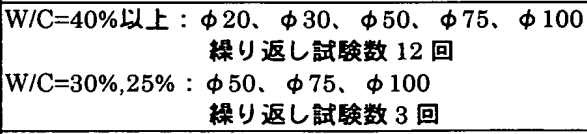 \\
\hline 水セメント比 & 5 & $\mathrm{~W} / \mathrm{C}=25 \%, 30 \%, 40 \%, 50 \%, 60 \%$ \\
\hline 試噥材睔 & 2 & 材䚙 4 週、13 週 \\
\hline 責生方法 & 1 & 摽準㯰生 \\
\hline
\end{tabular}

表ー 2 コンクリートの調合

\begin{tabular}{|c|c|c|c|c|c|c|c|c|}
\hline \multirow{2}{*}{$\begin{array}{l}\text { 水 } \\
\text { セx快 } \\
\text { 比 } \\
(\%)\end{array}$} & \multirow{2}{*}{$\begin{array}{l}\text { 細骨 } \\
\text { 材舞 } \\
(\%) \\
(\%)\end{array}$} & \multicolumn{4}{|c|}{ 質量 $\left(\mathrm{kg} / \mathrm{m}^{3}\right)$} & \multirow{2}{*}{$\begin{array}{c}\text { 高性能 } \\
\mathrm{AE} \\
\text { 減水都 } \\
(\mathrm{C} \times \%)\end{array}$} & \multirow{2}{*}{$\begin{array}{c}\mathrm{AE} \\
\text { 減水用 } \\
(\mathrm{C} \times \%)\end{array}$} & \multirow{2}{*}{$\begin{array}{c}\text { 補助 } \\
\mathrm{AE} \text { 刘 } \\
(\mathrm{A} \text { タイプ }\end{array}$} \\
\hline & & $\begin{array}{l}\text { 単位 } \\
\text { 水量 }\end{array}$ & $\begin{array}{c}\text { 単位 } \\
\text { 也x外 } \\
\text { 量 }\end{array}$ & 稩骨材 & 柤骨材 & & & \\
\hline 25 & 45.0 & 170 & 680 & 676 & 846 & 2.00 & - & - \\
\hline 30 & 45.0 & 165 & 550 & 738 & 928 & 2.00 & - & - \\
\hline 40 & 37.8 & 176 & 440 & 627 & 1059 & - & 0.25 & 3 \\
\hline 50 & 41.6 & 168 & 336 & 733 & 1059 & - & 0.20 & 3 \\
\hline 60 & 43.6 & 163 & 272 & 798 & 1059 & - & 0.20 & 3 \\
\hline
\end{tabular}

* Chief Research Engineer, Technical Research Institute, Obayashi Corporation

*2 General Manager, Technical Research Institute, Obayashi Corporation, Dr. Eng. 


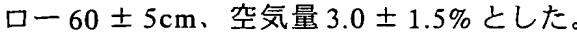

\section{1 .3 使用材料}

使用したセメントは、水セメント比 $40 \%$ 以上の調合では普通ポル トランドセメントを、水セメント比 $30 \%$ のものは低熱ポルトランド セメントを、水セメント比 $25 \%$ のものはシリカフュームセメントを それぞれ用いた。なお、粗骨材には最大寸法 $20 \mathrm{~mm}$ の砕石を用いた。

使用材料を整理して表 -3に示した。

\subsection{4 試験方法}

供試体は、標準の強度確認用の $\phi 100 \times 200$ シリンダーとコア供 試体成形用の $\phi 150 \times 300$ シリンダーを同一バッチで成型し、標準 養生を行った。

コア供試体の抜き取りは、強度試験材齢の 3 日前から実施し、直 径と高さの比が1:2となるようにコンクリートカッターで成形した。 成形後は試験時まで標準養生を続けた。なお、コア供試体の端面は、 研磨処理を施し、キャッピングを行っていない。研磨は、コア端面 が所定の平面度（0.05mm 以内）を満足するように行った。なお、コ ア直径が小さい $\phi 20$ と $\phi 30$ は、写真-1に示す供試体固定用の専用 治具を製作して行った。

コア供試体は、すべての試験条件で 3 本一組とした。直径 $\phi 75$ な らびに $\phi 100$ のコア供試体は、 1 本の $\phi 150 \times 300$ シリンダーから 1 本のコア供試体を、直径 $\phi 50$ 以下のコア供試体は、 1 本の $\phi 150$ × 300 シリンダーから 3 本のコア供試体を抜き取った。

コア供試体の抜き取りにはフリーセンターボール盤 (ボーリング マシン) を用いた。また、コアビットは、それぞれの直径が確保で きるものを用いた。コア供試体の抜き取りは、供試体側面に凹凸が 生じないよう慎重に行った。抜き取り速度はおよそ $1 \sim 2.5 \mathrm{~cm} / \mathrm{min}$ 程度であり、コア直径が小さいものほど抜き取り速度を早くした。 抜き取り状況を写真-2に示す。また、コアビットの交換は行ってい ない。

なお、水セメント比 $40 \%$ 以上のコンクリートを対象とした試験 は、12 回の繰り返し試験を、水セメント比 $25 \% 、 30 \%$ の超高強度コ ンクリートを対象とした試験は 3 回の繰り返し試験を行った。強度 試験に用いた試験機は、コア直径に係わらず全て $2000 \mathrm{kN}$ アムス ラー試験機を用いた。コア直径 $\phi 20$ の載荷状況を写真 -3 に示す。

この試験は、JIS A 1107 「コンクリートからのコア及びはりの切 り取り方法ならびに強度試験方法」に準じて行っている。

\section{2 モルタル試験}

コンクリートからコアを抜き取る際に、コア直径が小さい場合に は内部に含まれる粗骨材の存在が試験結果に多大な影響を与えると 推察される。ここでは、粗骨材のないモルタルを対象としてコンク リートと同じ方法でコア直径が試験結果に及ぼす影響を調査してみ た。

試験に用いたモルタルは、目標フロー $200 \mathrm{~mm}$ の 1 ：3モルタル とし、水セメント比は 50\%の 1 水準とした。コア供試体の直径は、 $\phi 20 、 \phi 30 、 \phi 50 、 \phi 75$ ならびに $\phi 100$ の 5 水準とし、2 回の繰 り返し試験とした。

供試体の成型方法、強度試験材齢、コア供試体成形方法などの試 験方法は、コンクリート試験と同じ方法で行っている。また、使用 材料は、セメントは普通ポルトランドセメントを用い、細骨材には コンクリート試験と同じものを用いた。
表一 3 使用材料

\begin{tabular}{|c|c|}
\hline 材料名 & 種類・性犋 \\
\hline セメント & $\begin{array}{ll}\text { W/C }=40 \% \text { 以上用 }: \text { 普通ポルトランドセメント（密度 } 3.16) \\
\text { W/C }=30 \% \text { 用 } & \text { : 低熱ポルトランドセメント (密度 } 3.22) \\
\text { W/C }=25 \% \text { 用 } & \text { : シリカフュームセメント }\end{array}$ \\
\hline 細骨材 & 木更津産山砂（密度（表乾）2.59、吸水率 1.86\%、粗粒率 2.50) \\
\hline 粗骨材 & $\begin{array}{r}\text { 青梅産砕石（硬質砂岩、最大寸法 } 20 \mathrm{~mm} \text { 、密度（表乾） } 2.66 \text { 、 } \\
\text { 吸水率 } 0.72 \% \text { 、粗粒率 } 6.76 \text { ） }\end{array}$ \\
\hline 混和威 & 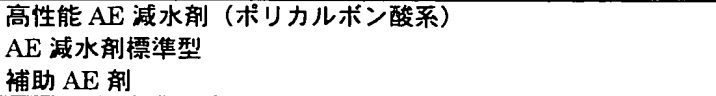 \\
\hline
\end{tabular}

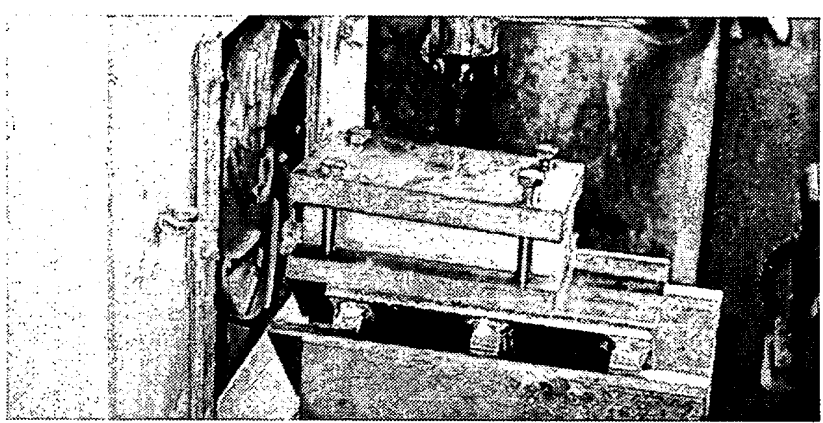

写真一１専用治具を使った研磨状況（コア直径 $\phi 20 ）$

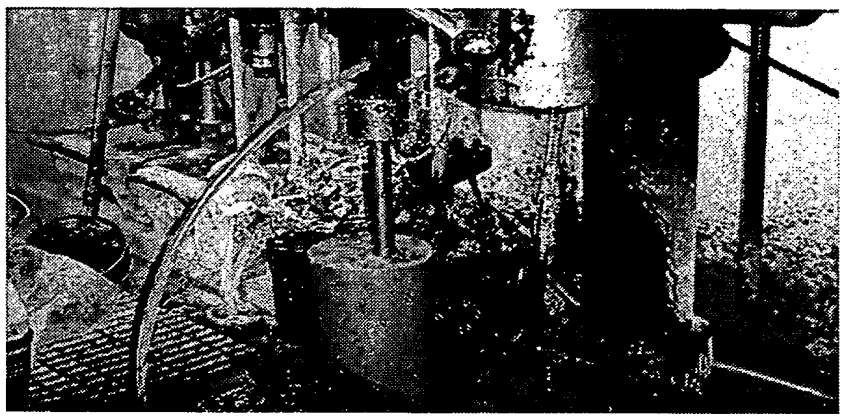

写真ー 2 コア抜き取り状況（コア直径 $\phi 20 ）$

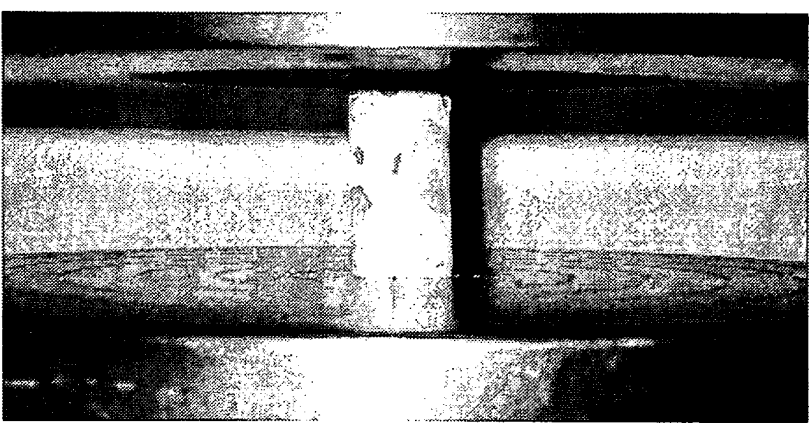

写真一－圧縮強度試験状況（コア直径 $\phi 20)$

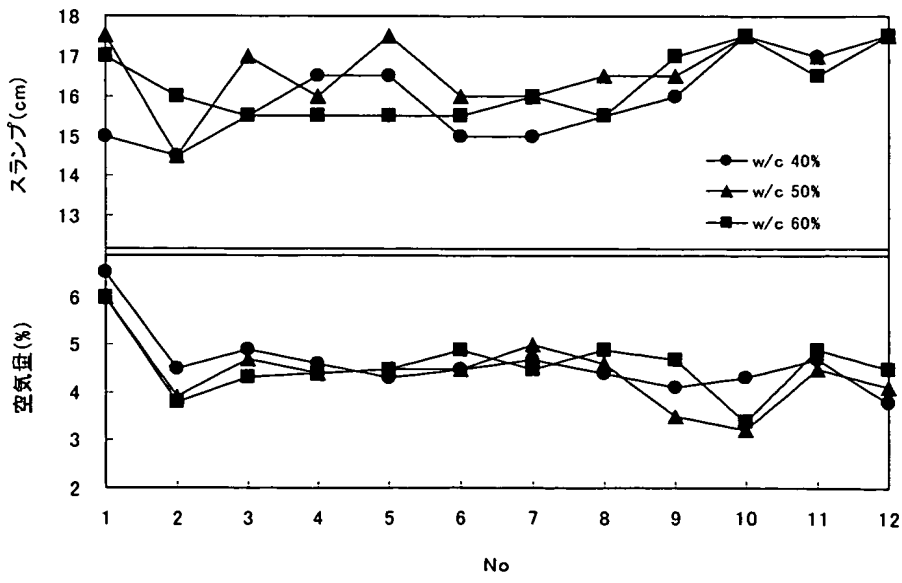

図ー1 フレッシュコンクリートの試験結果（W/C=40\% 以上） 
3. 試験結果と考察

3.1 コンクリート試験

3.1.1 フレッシュコンクリートの試験結果

水セメント比 $40 \%$ 以上の調合のコンクリートの供試体成型時のフ レッシュ性状を図-1に、水セメント比 $25 \% 、 30 \%$ の調合のフレッ シュ性状を図-2示す。これらの図から、ほほ目標とするフレッシュ

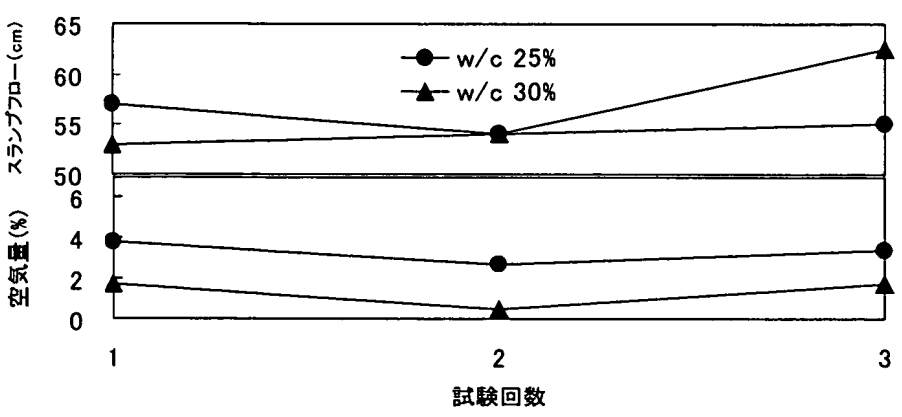

図ー2 フレシシコシクリートの試験結果（W/C=30\%以下）

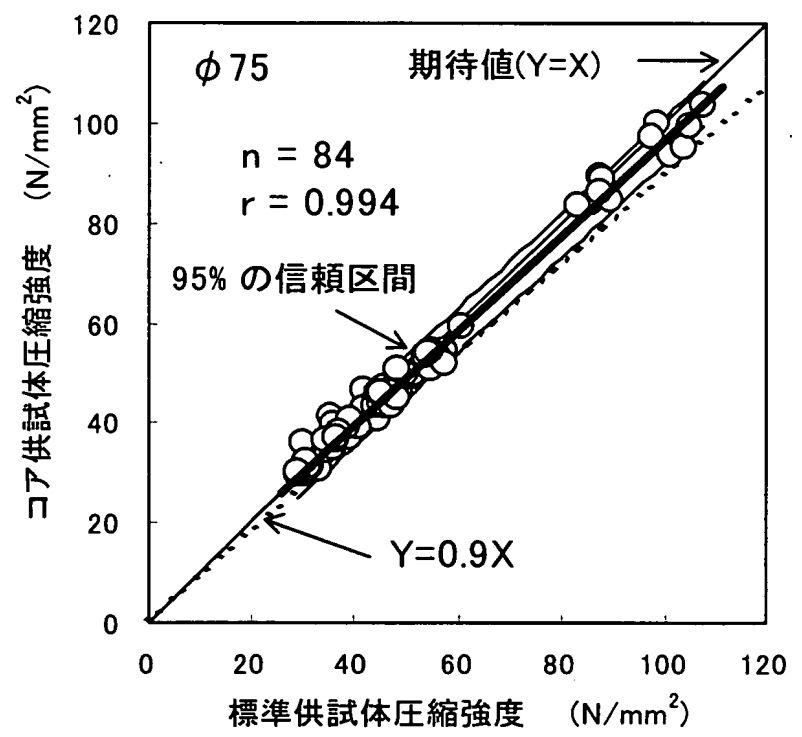

図ー4 コア直径 $75 \mathrm{~mm}$ 試験結果

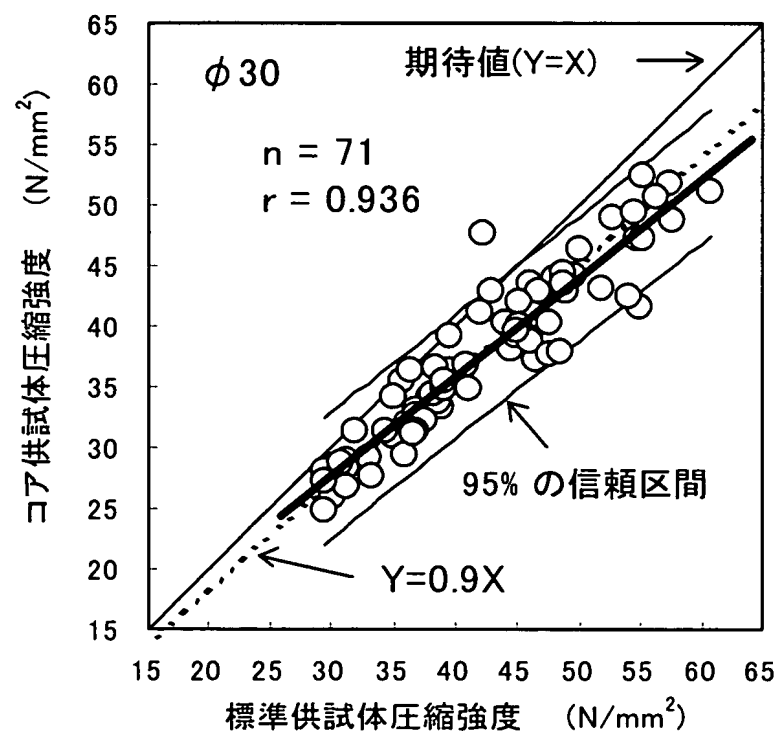

図一 $6 \cdot コ ア$ 直径 $30 \mathrm{~mm}$ 試験結果

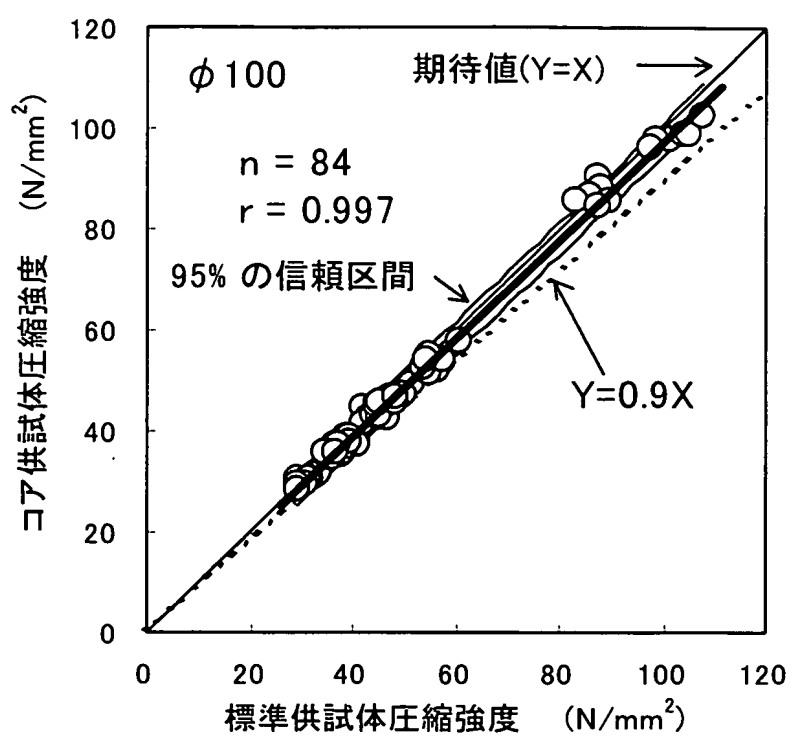

図一３コア直径 $100 \mathrm{~mm}$ 試験結果

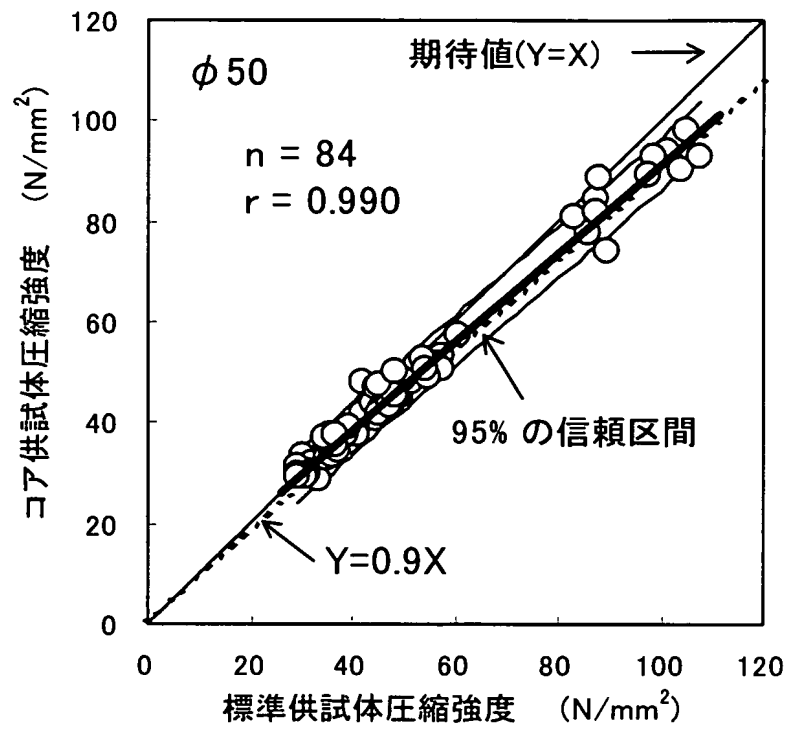

図ー5 コア直径 $50 \mathrm{~mm}$ 試験結果

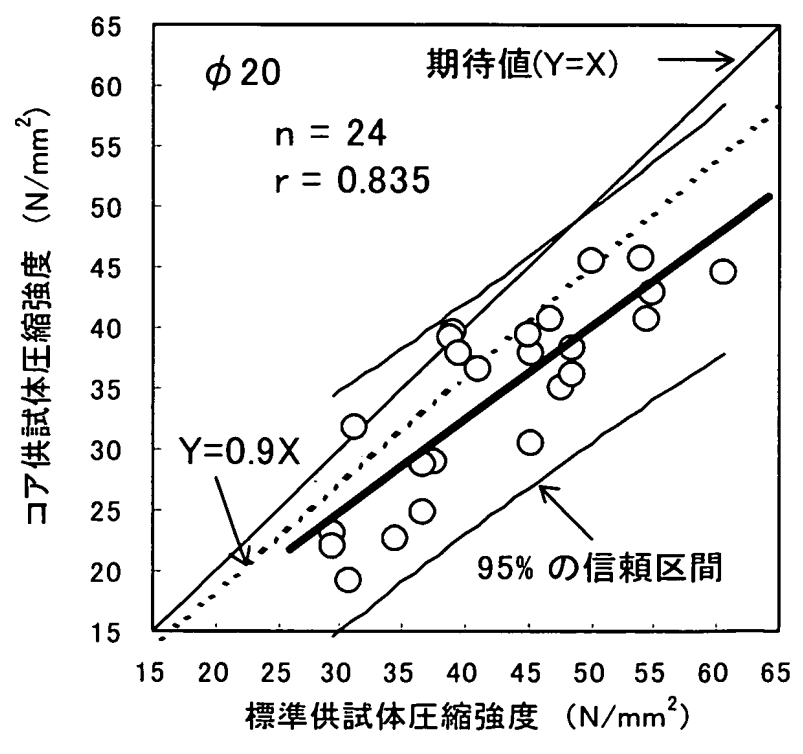

図ー7 コア直径 $20 \mathrm{~mm}$ 試験結果 
性状で供試体を成形することができた。

\section{1 .2 強度試験結果}

強度試験結果を図-3〜図-7に示した。図は、コア供試体強度を 綎軸、標準供試体強度を横軸としてプロットしている。プロットし ている点は、3本の供試体強度の平均值である。また、図には回帰 曲線、相関係数ならびにテータの 95\% 信頼区間を示した。

これらの図から、コア供試体の直径が小さくなるほど、期待値(図 中の $\mathrm{Y}=\mathrm{X}$ の直線）からのズレが大きくなり、95\%の信頼区間が広 がりテータのばらつきが大きくなっていること、この結果、当然の ことながら相関倸数も小さくなっていることがわかる。特に、コア 直径が $30 \mathrm{~mm}$ と $20 \mathrm{~mm}$ の場合は、圧縮強度が大きくなればなるほど 標準供試体強度との差が大きくなることがわかる。

また、コア直径 50mm 以上の図-3〜図-5では、水セメント比 $25 \%$ ならびに30\%のコンクリートの試験結果を合わせて示した。これら の図から、コア直径が $50 \mathrm{~mm}$ の場合、圧縮強度が約 $80 \mathrm{~N} / \mathrm{mm}^{2} \sim 110 \mathrm{~N} /$ $\mathrm{mm}^{2}$ 前後の超高強度域になると標準供試体強度に比べやや低下する 傾向が認められた。しかしながら、その低下の程度は、それほど大 きくない。

さらに、標準供試体強度の 90\%（図中の $\mathrm{Y}=0.9 \mathrm{X}$ の直線）以上の 評価が可能なコア直径について検討してみる。コア直径 $100 \mathrm{~mm}$ な らびに $75 \mathrm{~mm}$ の場合は、当然、超高強度域を含めて可能であると言 える。コア直径 $50 \mathrm{~mm}$ の場合は、 $60 \mathrm{~N} / \mathrm{mm}^{2}$ 以下では、 $90 \%$ をやや下 回るものがあるものの可能であると言える。また、 $60 \mathrm{~N} / \mathrm{mm}^{2}$ を超え る領域においても平均值での評価は出来るものと考えられる。一方、 コア直径が $30 \mathrm{~mm}$ 以下になると平均值での評価としてみても可能な 強度レベルは、コア直径 $30 \mathrm{~mm}$ で $40 \mathrm{~N} / \mathrm{mm}^{2}$ 程度以下、コア直径 $20 \mathrm{~mm}$ では今回のデータから類推して $20 \mathrm{~N} / \mathrm{mm}^{2}$ 程度以下とさらに小さくな ることがわかる。

なお、水セメント比 $40 \%$ 以上のコンクリートについては 12 回の 繰り返し試験を行ったが、試験結果の評価を大きく変えるようなも のはなかった。また、調合上の水セメント比や強度試験材齢の違い により試験結果の評価を変える必要は認められなかった。

これより、粗骨材最大寸法の 2 倍以下のコア直径つまり直径 $20 \mathrm{~mm}$ や $30 \mathrm{~mm}$ のコア供試体による強度試験では、試験結果のばら つきが大きくなると同時に得られた強度は実際の強度を過小評価す る傾向が強くなると言える。従って、構造体コンクリート強度をコ ア供試体強度で直接評価しようとした場合、コア供試体の直径は、 理縮強度がおおよそ $60 \mathrm{~N} / \mathrm{mm}^{2}$ 前後以下の場合は、少なくとも粗骨材 最大寸法の 2.5 倍、つまり、直径 $50 \mathrm{~mm}$ が必要であり、圧縮強度が $60 \mathrm{~N} / \mathrm{mm}^{2}$ 前後を超える場合は、粗骨材最大寸法の 3.5 倍の直径 $75 \mathrm{~mm}$ 以上が必要であると考えられる。

\section{2 モルタル試験}

モルタル強度試験結果を図-8に示した。図は、コア供試体強度を 縌軸、標準供試体強度を横軸としてプロットしている。プロットし ている点は、3本の供試体強度の平均值である。また、図には回帰 曲線を示した。

モルタル試験は、試験回数 2 回と少ないが、コア直径が小さい $30 \mathrm{~mm}$ と $20 \mathrm{~mm}$ の場合は、標準供試体圧縮強度との差が大きいこと がわかる。

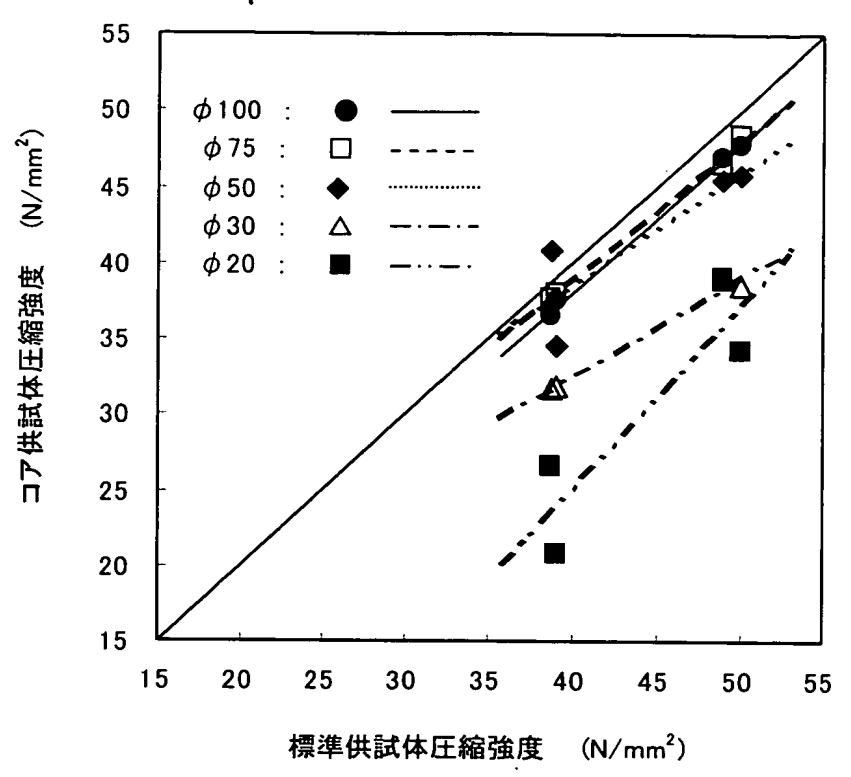

図ー8 モルタル試験結果

このように、粗骨材が含まれていなくても、コア直径が $30 \mathrm{~mm} や$ $20 \mathrm{~mm}$ の場合は、得られた強度は実際の強度を過小評価する傾向が あることが認められた。

\section{4. まとめ}

直径の異なるコア供試体の強度試験結果の信頼性について比較検 討した。その結果、以下のことが明らかになった。

コア直径が小さくなるほど、強度試験結果のばらつきが大きくな り、標準の強度試験結果に比べ、強度を過小評価する傾向が強くな る。

粗骨材最大寸法の 2.5 倍未満の直径のコア供試体を用いる場合に は、その試験結果の評価には注意する必要がある。

なお、コア供試体による構造体コンクリート強度の適切な確認は、 維持管理のための調查に限らず、最近の高強度コンクリートや超高 強度コンクリートの普及に伴って構造体コンクリート強度検査の判 定值に重大な影響を及ぼすS值を設定するための基本データとして コア供試体による構造体コンクリート強度の確認が求められる機会 が多くなった。

そのような場合に、コア抜き取り方法も含めたコア供試体による 強度試験方法の標準化が必要ではないかと考える。試験方法の標準 化に向けて今回の試験データが役に立てれば幸いである。

\section{考文献}

1) 谷川 苶雄 他:小径コアによる構造体コンクリート強度の推定法に関する 実験的研究（その1：供試体の寸法効果に関する研究）(その 2 : 圧樎強度試験 時の載荷方法が圧縮強度に及ほす影響)、日本建築学会大会学術講演梗概集、 pp705 708、1999.9

2) 笠井 芳夫 他: 小径コアによるコンクリートの圧縮試験方法、日本建築学会 大会学術講演梗概集、pp709〜 710、1999.9

[2001年10月19日原稿受理 2002 年 2 月 18 日採用決定］ 